\title{
Low Penetrance Genetic Variations in DNA Repair Genes and Cancer Susceptibility
}

\author{
Ravindran Ankathil \\ Human Genome Center, School of Medical Sciences \\ University Sains Malaysia, Health Campus \\ Kubang Kerian, Kelantan \\ Malaysia
}

\section{Introduction}

The genetic material, DNA, which encodes genes needed for the production of essential proteins, is vulnerable to damage in a number of ways. Human DNA is assaulted on a daily basis by a variety of exogenous factors including UV light, cigarette smoke, dietary factors, and other carcinogens all of which can cause varying degrees of DNA damage and can lead to mutations. Similarly, endogenous factors such as undue DNA replication which can cause mismatches, hydrolysis leading to spontaneous DNA depurination, replication form collapse which can result in strand breaks, loss of bases because of spontaneous disintegration of chemical bonds, and DNA damage secondary to endogenous reactants such as alkyl groups, metal cations, and reactive oxygen species (ROS) which can induce base oxidation and DNA breaks also contribute to DNA damage (Branzei \& Foiani, 2008; Capella et al., 2008)

When DNA is damaged, an intertwined network of surveillance mechanisms will act including

- Sensing and recognizing DNA damage by activation of cell cycle checkpoints, pause that permit assessment and complete of DNA processing, either DNA damage repair or processing of DNA intermediates

- Up regulation a large number of genes

- Programmed cell death or apoptosis when the cell is unable to repair the damage sustained and

- Elicitation of multiple distinct DNA repair responses

DNA damages are repaired by enzymes coded by one or more DNA repair pathways according to their structure, or their location in the cellular genome. DNA repair enzymes can be characterized as cellular proteins acting directly on damaged DNA in an attempt to restore the correct DNA sequence and structure. These relatively specialized enzymes appear to undertake the initial stages of recognition and repair of specific forms of DNA damage. Since there are various kinds of DNA damage, a variety of repair mechanisms are essential. Cells integrate DNA repair process with transcription and apoptosis through a network known as the DNA damage response (DDR) which is orchestrated by the checkpoint proteins. 


\section{DNA repair pathways}

Damages in DNA are repaired by various DNA repair genes belonging to distinct pathways. Each pathway is recognized for efficient repair of specific types of DNA damage. To date, more than 150 human DNA repair genes have been identified, which can be categorized into at least 5 distinct pathways: Base Excision Repair (BER), Nucleotide Excision Repair (NER), Mismatch Repair (MMR), Double Strand Break Repair (DSBR), and Transcription Coupled Repair (TCR) (Wood et al., 2005). The Base Excision Repair Pathway operates on small lesions such as oxidized or reduced bases, fragmented or nonbulky adduct, and adducts produced by methylating agents. The Nucleotide Excision repair (NER) pathway repairs bulky lesions such as pyramidine dimmers, other products of phytochemical reactions, large chemical adducts and DNA crosslinks. For Double Strand Break Repair (DSBR), at least two pathways exist: homologous recombination and non homologous end joining. Replication errors such as base-base or insert-deletion mismatches caused by the DNA polymerase are repaired by Mismatch Repair (MMR) pathway genes. Finally, the suicide enzyme methylguanine-DNA, methyl transferase, is an additional category of DNA repair pathway that directly removes the alkylated bases.

The repair gene products operate in a co-ordinated fashion to form repair pathways that control restitution of specific types of DNA damage. Repair pathways are further coordinated with other metabolic processes, such as cell cycle control, to optimize the prospects of successful repair. During the cell cycle, checkpoint mechanisms ensure that a cell's DNA is intact before permitting DNA replication and cell division to occur. Failures in these checkpoints can lead to an accumulation of damage, which in turn leads to mutations. Repair of damaged DNA is of paramount importance and is essential to prevent loss of or in correct transmission of genetic information, to prevent genetic damage from propagating and accumulating, to maintain genome integrity and stability of cells, and also to prevent mutations The failure of the cell to adequately repair the acquired damage and to undergo apoptosis may lead to further errors which can cause developmental abnormalities and neoplastic transformation of the cell and finally to carcinogenesis.

\section{Genetic susceptibility to cancer - High and low penetrance DNA repair genes}

Genetic susceptibility to cancer result from variations in the genetic code that alter either protein expression, function or localization. Susceptibility to cancer is determined by two types of genes - high penetrance genes and low penetrance genes. High penetrance genes are genes with allelic variants that confer a high degree of risk to the individual. Relatively few individuals in the population carry risk -increasing genotypes at these loci. The proportion of cancer in the population that may be explained by these genotypes will be low. Therefore the population attributable risk also will be low. But high penetrance genes have a large magnitude of effects on cancer risk and usually follow a mendelian autosomal domiant pattern of inheritance and involve multiple cancer sites that form a cancer syndrome. High penetrance genes with an attendant high likelihood of causing cancer, account for only a small proportion of cancer cases. In humans, high penetrance DNA repair genes that cause family or hereditary cancer syndromes can have substantial impact in affected families (eg: BRCA1 and BRCA2 genes in hereditary breast cancer, DNA Mismatch Repair (MMR) genes in Hereditary Non Polyposis Colorectal Cancer (HNPCC), p53 in 
LiFraumeni Syndrome). But these genes affect only a small portion of cancer cases and a small percent age of the population.

Loss of function mutations in a significant number of DNA damage response genes predispose to a variety of familial cancers (Spry et al., 2007). There are several examples such as mutations in BRCA1 and BRCA2 belonging to homologous recombination pathways predispose to breast and ovarian cancer (Bertwistle \& Ashworth, 2000). So also, mutations in other double strand break repair genes such as ATM predispose to the familial tumorigenic condition ataxia telangiectasia (Lavin \& Shiloh 1996) and breast cancer (Renwick et al., 2006). Mutations in NBSI have been reported to predispose to Nijwegen breakage syndrome (Matsuura et al., 2004). Somatic mutations in another DSB repair gebe, ATR, correlate with sporadic microsatellite (MSI) positive stomach cancer (Menoyo et al., 2001). PALB2 gene, which encodes a BRCA2 indicating protein, has also been identified as a breast cancer susceptibility gene (Rahman et al., 2007). Mutations in a group of DNA mismatch repair (MMR) gene predispose to hereditary non-poplyposis colorectal cancer and other cancers in the extra colonic sites in Lynch syndrome (Jacob \& Praz, 2002). Biallelic germline mutations of the base excision repair gene MUTYH have been identified in patients with autosomal recessive form of hereditary multiple colorectal adenoma and carcinoma (Jones et al., 2002). Defect in the nucleotide excision repair pathway genes predispose to xeroderma pimentosum (XP), Cockayne syndrome (CS) and Trichothiodystrophy (TTD), which are all autosomal recessive syndromes (Leibeling et al., 2006).

In contrast, in the remaining major portion of sporadic cases, genetic variations in the form of low to moderate penetrance alleles may predispose individuals to cancer in combination with environmental factors and thus affect a large segment of the population. Low penetrance genes, also referred to as modifier genes, are genes in which subtle sequence variants may be associated with a small to moderate increased relative risk for sporadic cancers.

\section{Single Nucleotide Polymorohisms (SNPs) in low penetrance genes}

Genetic variations seen in human genome includes insertion/deletion of one or more nucleotides (indels) the copy number variations (CNNs) that can involve DNA sequences of a few kilobases up to millions of bases and single nucleotide polymorphisms (SNPs) which are the substitution of a single nucleotide along the DNA. With an estimated number of more than 10 million to be present in the human genome, SNPs are the most common form of genetic variation (Miller et al., 2005).

Variations in several classes of low penetrance genes known as Single nucleotide polymorphism (SNPs) are very common in the population. SNPs are DNA sequence variations that occur when a single nucleotide $(A, T, C$, or $G)$ in the genome sequence is altered. For a variation to be considered as SNP, it must be present in at least $1 \%$ of the population. SNPs are relatively common in the population and as such may be associated with a much higher attributable risk in the population as a whole than the rare high penetrance genes. Therefore, variants in low penetrance genes could explain a greater proportion of sporadic cancers than the high penetrance genes. SNPs acting together with environmental factors are well documented candidates for cancer susceptibility. Even though, SNPs in these low penetrance genes have only small effect when considered singly, they may produce a high risk profile when acting together with other shared genetic variants and environmental factors (Gary et al., 1999). On the basis of biological plausibility, 
SNPs in low penetrance genes whose protein products would affect a pathway involved in carcinogenesis have been documented as cancer predisposition or susceptibility risk factors. Low penetrance candidates are found in a wide variety of pathways ranging from metabolism and detoxification or environmental carcinogens to DNA damage repair.

The recognition that carcinogens can also be mutagens that change the DNA sequence gave impetus to the relevance of DNA damage and repair to carcinogenesis. All the effects of exogenous factors and endogenous factors on tumor production could be accounted for by the DNA damage that they cause and by the errors introduced into DNA during the cell's efforts to repair this damage. According to the mutator phenotype hypothesis, cancer phenotypes result from mutations in genes that maintain genetic stability in normal cells. Mutations in genetic stability genes can cause mutations in other genes that govern genetic stability, initiating a cascade of mutations throughout the genome. So, the prompt response of the cells to repair genetic injury and its ability to maintain genomic stability by means of a variety of DNA repair mechanisms are therefore essential in preventing tumor initiation and progression.

Genetic variants or mutations in high penetrance genes are disease causing whereas genetic variations in low penetrance genes are insufficient to cause cancer, but may influence cancer risk. So genetic variants in low penetrance genes are disease risk associated. Individual low penetrance risk alleles are insufficient to cause cancer, but influence cancer risk. Low penetrance genes, with an attendant increased risk of causing cancer, albeit, less likely than high penetrance genes (Ponder, 2001; Shields \& Harris, 2000) predispose individuals to cancer upon interacting with environmental factors.

\section{SNPs in DNA damage repair genes}

DNA repair mechanisms are controlled by specific set of genes encoding the enzymes that catalyze cellular response to DNA damage. It is well documented that loss of repair function, or alteration of the control of repair process, can have very serious consequences for cells and individuals and can lead to development of cancer. Several genes involved in DNA repair pathways are considered to be low penetrance genes. A link between failure of DNA repair and carcinogens was suggested when individuals with chromosome breakage syndrome such as Xeroderma Pigmentosum, Fanconi Anemia, Bloom Syndrome, Ataxia telangiectasia who have inherited genetic defects in certain DNA repair systems were recognized to be at an increased susceptibility to development of certain cancers.

Because DNA damage is associated with cancer development, it was hypothesized that genes involved in DNA damage repair may influence cancer susceptibility. Polymorphisms in DNA repair genes may be associated with differences in the DRC of DNA damage and may influence an individual's risk for cancer, because the variant genotype in those polymorphisms might destroy or alter repair function. A large number of SNPs have been determined among individuals in DNA repair genes. It has been documented that genetic variations in DNA damage repair genes could result in variations in efficacy and accuracy of DNA repair enzymes and could have effect on the sensitivity of the organism to environmental genotoxins.

Genetic variation in DNA repair genes in each of the five DNA repair pathways has been implicated in cancer susceptibility (Berwick \& Vineis 2000; Goode et al., 2002). Genetic variations such as SNPs in DNA repair genes are associated with reduced function of their encoded proteins, rather than absence of function and may alter an individual's capability to 
repair damaged DNA. This may result in gene product (protein) not being formed, or that the protein is less active, or that it is formed in an uncontrolled fashion, may be at the wrong time, or in the wrong amount. Some minor genetic alterations may not affect protein activity, or interactions, whereas others may significantly disrupt cellular function. It is also possible that since certain proteins work in a number of different processes or complexes, the loss or impairment of one type of protein can affect several different functions of the cell and organism. Deficiency or impairment in DNA repair genes which results in alteration of the key gene expression may have an influence on DNA repairs functions and could lead to altered cancer risk. The importance of these mechanisms in cancer prevention is evident from the increased cancer risk associated with disruption of these pathways (Digweed, 2003). So studies on DNA repair as a susceptibility factor for cancer are increasing exponentially. Majority of cancer susceptibility studies have focused on the identification of low-penetrance disease susceptibility alleles applying candidate gene pathway studies and genome wide association studies. Genetic association studies and genome wide association scans have identified a number of polymorphisms in several low penetrance genes and their role in etiology of several cancers, through risk modification (Tomlinson et al., 2008).

DNA double strand breaks (DSBs) which can result from a variety of factors including ionizing radiation, free radicals, replication errors, telomere dysfunction are one of the most severe types of DNA damage (Khanna \& Jackson, 2001). Unpaired or misrepaired DSBs can lead to cell death, genomic instability and oncogenic transformation (Jeggo \& Jackson, 2001). Homologous recombination (HR) and nonhomologous enjoining (NHEJ) are the two major DSB repair pathways in mammalian cells. Reports are available suggesting that several Single Nucleotide Polymorphisms in the NHEJ genes may be relevant to modify the risk of multiple myloma (Roddam et al., 2002), glioma (Liu et al., 2008) and, breast cancer (GarciaClosas et al., 2006). Another study by (Tseng et al., 2009), showed significant association between the XRCC4 and LIGH genotypes with non-small cell lung cancer (NSCLC) risk in an analysis of individual polymorphism associations, and the risk of NSCLC increased further in a combined analysis of multiple polymorphisms.

\section{XRCC3}

The X-ray repair cross-complementing group 3 (XRCC3), the DNA repair gene which codes for a protein participating in homologous recombination repair (HRR) of double strand breaks (DSB), has been of considerable interest as a candidate gene for cancer susceptibility. The variant allele of the Thr241Met had been reported to have relatively high DNA adduct levels in lymphocyte DNA and hence with relatively low DNA repair capacity (Matullo et al., 2001). Several molecular epidemiologic studies have been performed to evaluate the role of XRCC3 polymorphisms such as XRCC3 4541 A>G, XRCC3 17893 A>G, XRCC3 Thr 241 Met on various neoplasms, such as cancer of breast, lung, bladder, colorectal, head and neck, skin etc (Han et al., 2004; Shen et al., 2004; Ritchey et al., 2005; Jin et al., 2005; Matullo et al.,2005; Garcia-Closas et al., 2006; Zienoldding et al., 2006; Yi et al., 2006). But rather than conclusive, the results from these studies remain fairly conflicting. Ahmd Aizat (2011) reported lack of association of XRCC3 Thr 241 Met with sporadic colorectal cancer susceptibility in Malaysian population. (Han et al., 2006) performed a meta -analysis on XRCC3 polymorphism and cancer risk involving 48 case-control studies including 24,975 cancer patients and 34,209 controls. From the analysis results, (Han et al., 2006) reported that 
individuals carrying the XRCC3 Met/Met genotype showed a. small cancer risk under a recessive genetic model. Specifically, the XRCC3 Met/Met genotype showed significantly increased risk of breast cancer, but not significant risk of cancer for head and neck, bladder, and non-melanoma skin cancer. This meta analysis results support that the XRCC3 might represent a low penetrance susceptible gene especially for cancer of breast, bladder, head and neck, and non-melanoma skin cancer.

\section{XRCC1}

The X-Ray Cross Complementing group I XRCC1 gene belongs to The Base Excision Repair IBER) pathway. The XRCC1 gene product plays an important role in the BER pathway by acting as a scolfold for the other DNA repair proteins, such as DNA polymerase B (Kubota et al., 1996), and DNA ligase III (Caldecott, 2003). Few common single nucleotide polymoprhisms of the XRCC1 gene have been identified at codon 194 (G>T substitution at position 26304, exon 6, Arg to Trp), codon 280 (G>A substitution at position 27466, exon 9, Arg to His) and 399 (G>A substitution at position 28152, exon 10, Arg to Gln). The individuals carrying XRCC1 399 variants have been shown to have higher levels of DNA adduct (Lunn et al., 2000) and to be at greater risk for tobacco related DNA damage (Lei et al., 2002). Few studies reported XRCC1 399AA genotype to be significantly associated with lung cancer risk in Caucasian population (Divine et al., 2001; Zhou et al., 2003), Korean population (Park et al., 2002), and Indian population (Sreeja et al., 2008).

\section{XPD (ERCC2)}

Xeroderma Pigmentosum group D (XPD) also known as ERCC2 (Excision Repair Cross Completing group 2) gene encodes a helicase, a major DNA repair protein, which is involved in transcription-coupled NER and in the removal of a variety of structurally unrelatedas DNA lesions (Lehmann, 2001) including those induced by tobacco carcinogens (Leadon \& Cooper, 1993), (Tang et al., 2002). The normal functioning XPD protein plays an essential role in NER and participates in the unwinding of DNA at the site of deleterious DNA lesions (Hoeijmakers et al., 1996). Several studies have reported association between A751C variant of XPD and increased risk of lung cancer (Hou et al., 2002; Spitz et al 2003; Ramachandran et al., 2006). Hou et al., 2003 reported a marginally increased risk for those carrying heterozygous $\mathrm{A}>\mathrm{C}$ transversions, compared to those with wildtype homozygous, indicating that heterozygosity also carry the risk. In a Northeastern Chinese population, XPD 751 AC heterozygous genotype carriers were at 2.7 fold higher risk of lung cancer than carrier of AA genotype (Yin et al., 2006). A significant association of XPD variants in modulating NSCLC risk was reported by Zienolddiny et al (2006) in Norwegian lung cancer population. So also, in an Indian population, Sreeja et al., (2008) also reported significant association of XPD heterozygous variants in modulating Non small cell lung cancer risk. SNPs in genes involved in nucleotide excision repair (ERCC1, XPD, XPC, XPA, XPF and $\mathrm{XPG}$ ) and mismatch repair genes (MLH1 and MSH2) in 577 colorectal cancer cases and 307 case-affected sibling controls were examined by Joshi et al., (2009). Their results showed that consumption of red meat, heavily brown on the outside or inside, increased colorectal cancer risk only among subjects with XPD codon 751 Lys/Lys or XPD codon 312 Asp/Asp genotypes. 


\section{P53}

The P53 gene plays a critical role in cell cycle control, the initiation of apoptosis, and maintenance of genomic stability and in DNA repair (Levine, 1997). TP53 is highly polymorphic in coding and non coding regions and some of these polymorphisms have been shown to increase cancer susceptibility and modify cancer phenotypes in TP53 mutation carriers (Whibley et al., 2009). Over 80 TP53 polymorphisms have been identified and validated in human populations. (IARC TP53 Database, R13). Nearly $90 \%$ are located in introns, outside splice sites, or in non coding exons. Among the P53 polymorphism, the codon 72 polymorphism (Arg72 Pro) in exon 4 of TP53 is the most extensively studied, both in experimental and population studies. Codon 72 is located within a proline rich region and Arg72 has been reported to be more effective in inducing apoptosis than Pro72. The Arg/Pro polymorphism at codon 72 of the P53 gene alters the ability of the P53 protein to induce apoptosis, influences the behaviour of mutant P53, decreases the DNA repair capacity and has been linked to with an increased risk of cancer, especially lung cancer. Several studies have examined the associations between P53 codon 72 (Arg72Pro) polymorphism and risk of different cancers, but with in consistent results. Few studies reported higher risk for lung cancer in individuals with the Arg/Pro or Pro/Pro genotype and especially Pro/Pro genotype with smoking induced lung cancer (Weston et al., 1992; Jin et al., 1995 ; Fan et al., 2000; Zhou et al., 2001). In a Chilean population, Fan et al., (2000) investigated the influence of polymorphic genotype TP53 on lung cancer susceptibility and the Pro/Pro genotype of TP53 was found to contribute significantly to lung cancer susceptibility risk [ OR 3.88 (95\% CI 1.16 - 13.39) ]. The study by Alexandrov et al (2002) were consistent with the hypothesis that Benzo(a)pyrene (Polycyclic aromatic hydrocarbon, PAH) induce $\mathrm{G}: \mathrm{C}$ to $\mathrm{T}: \mathrm{A}$ transverse mutations in the hotspot codons of TP53 and are hence involved in the malignant transformation of the lung tissue of smokers. In an Indian case - control study involving 211 lung cancer cases and 211 controls, Sreeja et al (2007) reported an OR of 2.5 (95\% CI 1.4704 .302 , p= 0.001) for the TP53 Pro/Pro variant genotype for lung cancer susceptibility and the risk tended to be higher for women [ OR $=2.4, p=0.003$ ] . Recently, Ahmd Aizat (2011) reported a significant association of Pro/Pro homozygous variant of p53 with sporadic colorectal cancer susceptibility $(\mathrm{OR}=1.886, \mathrm{CI}: 1,046-3.399, \mathrm{p}=0,035)$ and suggested that p53 Pro72Pro genotype carriers might be having a higher risk for Colorectal cancer susceptibility in Malaysian population (personal communication, unpublished data) However, meta-analysis on the risk association of TP53 Arg72Pro polymorphism with lung cancer (Matakidou et al., 2003) and breast cancer (Schmidt et al., 2007) do not support a significant role for this polymorphism in susceptibility.

\section{MMR genes}

In the maintenance of genomic stability, the DNA mismatch repair (MMR) systems comprising of various MMR genes play a key role. MMR genes mediate DNA repair through removal of mismatched nucleotide pairs and insertion/ deletion heterologies generated during DNA replication. Germ line mutations as well as hypermethylation in MMR genes have been reported in familial/hereditary forms of colorectal cancer. So, it was hypothesized that common variants in relevant genes encoding DNA MMR enzymes might impact the risk of sporadic form of CRC and studies have been carried out to explore this possibility. Even though the functional relevance of majority of polymorphisms in the genes 
involved in MMR is not known, recent studies suggest an influence of SNPs or biochemical interaction between components of the MMR pathways or on epigenetic mediated functional regulation (Chen et al., 2007).

Several common polymorphisms in DNA repair genes representing different repair pathways have been reported. Many studies have been carried out to elucidate the association between DNA repair gene polymorphisms and cancer susceptibility. But studies have shown inconsistent associations. The impact of many these polymorphisms on repair phenotype and cancer susceptibility remain uncertain (Berwick \& Vineis, 2000; Au et al., 2004). In a study on 5 DNA repair genes (XRCC1 Arg194Trp and Arg399gln, PARP Val762Ala and Lys940Arg, XPD Asp312Asn and Lys751Gln, OGG1 Ser326Cys MGMT Leu84Phe) in Singaporean Chinese population, Stern et al., (2007) provided support to the hypothesis that selected variants in DNA repair genes may contribute to colorectal cancer risk and may modify the effects of relevant life style risk factors that have been inconsistently associated with the disease. This study which reported the overall effects of PARP on colorectal cancer risk and XRCC1 SNPs as modifiers of the effects of smoking and alcohol on colorectal cancer risk, also highlighted the role of the base excision repair pathway in colorectal carcinogenesis. Vinies et al (2009) conducted meta-analyses of 241 associations between variants in DNA repair genes and cancer and had found sparse association signals with strong epidemiological credibility. Using 1087 datasets and publicly available data from genome wide association platforms, meta-analysis using dominant and recessive models were performed on 241 associations between individual variants and specific cancer types that had been tested in two or more independent studies. Thirty one nominally statistically significant $(\mathrm{P}<0.05$ without adjustment for multiple comparisons) associations were recorded for 16 genes in dominant and/or recessive model analyses (BRCA2, CCND1, ERCC1, ERCC2, ERCC4, ERCC5, MGMT, NBN, PARP1, POL1, TP53, XPA, XRCC1, XRCC2, XRCC3 and XRCC4). XRCC1, XRCC2, TP53, and ERCC2 variants were each nominally associated with several types of cancer. Three associations were graded as having "strong" credibility, another four had "modest" credibility and 24 had "weak" credibility based on Vinies criteria. Requiring more stringent $P$ values to account for multiplicity of comparisons, only the associations of ERCC2 codon 751 (recessive model) and of XRCC1-77 T $>C$ (dominant-model) with lung cancer had $\mathrm{P} \leq 0.0001$ and retained $\mathrm{P} \leq$ 0.001 even when the first published studies on the respective associations were excluded. The analyses suggested that the vast majority of postulated associations between DNA repair alleles and cancer risk have not been replicated sufficiently to give them strong credibility. This meta-analysis implies that larger scale studies would be necessary to establish specific associations of genetic variants in DNA repair and cancer and that the added risk conferred by single variants in DNA repair genes may be small. In another recent meta analysis, (Kiyohara et al.) found XPA G23A, OGG1 Ser326Cys and XPD Lys751Gln polymorphisms were associated with lung cancer risk .

\section{Limitations and future prospectives}

In SNP association studies, the most important critical point is associated with often too small size of cohort of cases and controls, resulting in a low statistical power and false, by chance, positive or negative outcomes. Another important aspect concerns inclusion of different ethnic groups. Different results may be expected due to intrinsic difference in genetic background among Caucasians, Asians, Afro Americans and other ethnic groups. 
There is wide population variability in repair capability phenotype on account of the variation in the polymorphic allele frequencies of DNA repair genes between different ethnic groups. Even through majority of SNPs are common to at least three historic human populations (Caucasians, Africans, Asians), some SNPs are specific to different ethnicities. These differences among human populations has highlighted the need to consider ethnic genetic differences while conducting genetic association studies evaluating disease risk, treatment response and outcome studies. This could also be accounting for a several fold variation in cancer risk and significant heterogeneity across all included studies. So susceptibility factor in one population may not be a factor in another population. Thus, different study designs, differences in the prevalence of genetic polymorphisms and linkage disequilibrium in different ethnic populations are possible explanations for the varying results obtained in different studies across the world. Effect modification by environmental or other genetic risk factors that differ between study populations are also alternative causes. This warrants the need to undertake large studies on homogeneous populations to avoid such influences. .

It is hoped that in future, advances in genotyping utilizing high throughput genotyping methods could facilitate the analysis of multiple polymorphisms within DNA repair genes and also the analysis of multiple genes within DNA repair pathways. Data generated from multiple polymorphisms within a gene can be combined to create haplotypes, the set of multiple alleles on a single chromosome. Because of higher heterozygosity and tighter linkage disequilibrium within disease causing mutations, haplotype analysis can increase the power to detect disease associations. Haplotype analysis also allows for the possibility of an ungenotyped functional variant to be in linkage disequilibrium with the genotyped polymorphisms. Investigations on gene-gene interactions or pathway analysis also would provide more comprehensive insight into the role of low penetrance genetic variants of DNA repair genes in cancer susceptibility. The identification of common, moderate or low penetrance genes for cancer will potentially be of great benefit, because it allows screening to be targeted to those at greatest risk which in turn will help in implementing cancer prevention strategies.

\section{Acknowledgements}

The author would like to express his sincere thanks and gratitude to Mr. Ahmad Aizat and Mr. Au Zian Liang, postgraduate students in Human Genome Center, University Sains Malaysia, Malaysia for their valuable help in word processing and reference collection related to this work.

\section{References}

Ahmad Aizat AA, Siti Nurfatimah MS, Aminudin MB, Biswa BM, Venkatesh RN, Zaidi Z, Ahmad Shanwani MS, Ankathil R. Polymorphism Thr241Met of the XRCC3 Gene and Lack of Association with Colorectal Cancer Susceptibility Risk among Malaysian Population -A Preliminary Report (Accepted to publish in International Medical Journal in next issue)

Ahmad Aizat AA , Siti Nurfatimah MS, Aminudin MM, Zaidi Z , Ahmad Shanwani MS , Muhammad Radzi AH , Ankathil R. Increased risk of sporadic Colorectal Cancer 
in Pro/Pro 72 genotype carriers of TP53 Arg72Pro polymorphism- A Malaysian case control study (In press)

Alexandrov, K. Cascorbi, I. Rojas, M. Bouvier, G. Kriek, E. \& Bartsch, H. (2002). CYP1A1 and GSTM1 genotypes affect benzo[a]pyrene DNA adducts in smokers' lung: comparison with aromatic/hydrophobic adduct formation. Carcinogenesis. 23(12): 1969-1977.

Au, W. W., Navasumrit, P. \& Ruchirawat, M. (2004) Use of biomarkers to characterize functions of polymorphic DNA repair genotypes. Int J Hyg Environ Health, 207, 30113.

Bertwistle, D. \& Ashworth, A. (2000) BRCA1 and BRCA2. Curr Biol, 10, R582.

Berwick, M. \& Vineis, P. (2000) Markers of DNA repair and susceptibility to cancer in humans: an epidemiologic review. J Natl Cancer Inst, 92, 874-97.

Branzei, D. \& Foiani, M. (2008) Regulation of DNA repair throughout the cell cycle. Nat Rev Mol Cell Biol, 9, 297-308.

Caldecott, K. W. (2003) XRCC1 and DNA strand break repair. DNA Repair (Amst), 2, 955-69.

Chen, H., Taylor, N. P., Sotamaa, K. M., Mutch, D. G., Powell, M. A., Schmidt, A. P., Feng, S., Hampel, H. L., De La Chapelle, A. \& Goodfellow, P. J. (2007) Evidence for heritable predisposition to epigenetic silencing of MLH1. Int J Cancer, 120, 1684-8.

Digweed, M. (2003) Response to environmental carcinogens in DNA-repair-deficient disorders. Toxicology, 193, 111-24.

Divine, K. K., Gilliland, F. D., Crowell, R. E., Stidley, C. A., Bocklage, T. J., Cook, D. L. \& Belinsky, S. A. (2001) The XRCC1 399 glutamine allele is a risk factor for adenocarcinoma of the lung. Mutat Res, 461, 273-8.

Fan, R., Wu, M. T., Miller, D., Wain, J. C., Kelsey, K. T., Wiencke, J. K. \& Christiani, D. C. (2000) The p53 codon 72 polymorphism and lung cancer risk. Cancer Epidemiol Biomarkers Prev, 9, 1037-42.

Garcia-Closas, M., Egan, K. M., Newcomb, P. A., Brinton, L. A., Titus-Ernstoff, L., Chanock, S., Welch, R., Lissowska, J., Peplonska, B., Szeszenia-Dabrowska, N., Zatonski, W., Bardin-Mikolajczak, A. \& Struewing, J. P. (2006) Polymorphisms in DNA doublestrand break repair genes and risk of breast cancer: two population-based studies in USA and Poland, and meta-analyses. Hum Genet, 119, 376-88.

Gary, R., Park, M. S., Nolan, J. P., Cornelius, H. L., Kozyreva, O. G., Tran, H. T., Lobachev, K. S., Resnick, M. A. \& Gordenin, D. A. (1999) A novel role in DNA metabolism for the binding of Fen1/Rad27 to PCNA and implications for genetic risk. Mol Cell Biol, 19, 5373-82.

Gilad, S., Bar-Shira, A., Harnik, R., Shkedy, D., Ziv, Y., Khosravi, R., Brown, K., Vanagaite, L., Xu, G., Frydman, M., Lavin, M. F., Hill, D., Tagle, D. A. \& Shiloh, Y. (1996) Ataxia-telangiectasia: founder effect among north African Jews. Hum Mol Genet, 5, 2033-7.

Goode, E. L., Ulrich, C. M. \& Potter, J. D. (2002) Polymorphisms in DNA repair genes and associations with cancer risk. Cancer Epidemiol Biomarkers Prev, 11, 1513-30.

Han, J., Colditz, G. A., Samson, L. D. \& Hunter, D. J. (2004) Polymorphisms in DNA doublestrand break repair genes and skin cancer risk. Cancer Res, 64, 3009-13.

Han, S., Zhang, H. T., Wang, Z., Xie, Y., Tang, R., Mao, Y. \& Li, Y. (2006) DNA repair gene XRCC3 polymorphisms and cancer risk: a meta-analysis of 48 case-control studies. Eur J Hum Genet, 14, 1136-44. 
Hoeijmakers, J. H., Egly, J. M. \& Vermeulen, W. (1996) TFIIH: a key component in multiple DNA transactions. Curr Opin Genet Dev, 6, 26-33.

Hou, S. M., Falt, S., Angelini, S., Yang, K., Nyberg, F., Lambert, B. \& Hemminki, K. (2002) The XPD variant alleles are associated with increased aromatic DNA adduct level and lung cancer risk. Carcinogenesis, 23, 599-603.

Hou, S. M., Ryk, C., Kannio, A., Angelini, S., Falt, S., Nyberg, F. \& Husgafvel-Pursiainen, K. (2003) Influence of common XPD and XRCC1 variant alleles on p53 mutations in lung tumors. Environ Mol Mutagen, 41, 37-42.

Jacob, S. \& Praz, F. (2002) DNA mismatch repair defects: role in colorectal carcinogenesis. Biochimie, 84, 27-47.

Jeggo, P. A. \& Lobrich, M. (2006) Contribution of DNA repair and cell cycle checkpoint arrest to the maintenance of genomic stability. DNA Repair (Amst), 5, 1192-8.

Jin, X., Wu, X., Roth, J. A., Amos, C. I., King, T. M., Branch, C., Honn, S. E. \& Spitz, M. R. (1995) Higher lung cancer risk for younger African-Americans with the Pro/Pro p53 genotype. Carcinogenesis, 16, 2205-8.

Jones, S., Emmerson, P., Maynard, J., Best, J. M., Jordan, S., Williams, G. T., Sampson, J. R. \& Cheadle, J. P. (2002) Biallelic germline mutations in MYH predispose to multiple colorectal adenoma and somatic G:C-->T:A mutations. Hum Mol Genet, 11, 2961-7.

Joshi, A. D., Corral, R., Siegmund, K. D., Haile, R. W., Le Marchand, L., Martinez, M. E., Ahnen, D. J., Sandler, R. S., Lance, P. \& Stern, M. C. (2009) Red meat and poultry intake, polymorphisms in the nucleotide excision repair and mismatch repair pathways and colorectal cancer risk. Carcinogenesis, 30, 472-9.

Khanna, K. K. \& Jackson, S. P. (2001) DNA double-strand breaks: signaling, repair and the cancer connection. Nat Genet, 27, 247-54.

Kiyohara, C., Takayama, K. \& Nakanishi, Y. (2010) Lung cancer risk and genetic polymorphisms in DNA repair pathways: a meta-analysis. J Nucleic Acids, , 701-760.

Kubota, Y., Nash, R. A., Klungland, A., Schar, P., Barnes, D. E. \& Lindahl, T. (1996) Reconstitution of DNA base excision-repair with purified human proteins: interaction between DNA polymerase beta and the XRCC1 protein. EMBO J, 15, 6662-70.

Lavin, M. F. \& Shiloh, Y. (1996). Ataxia telangiectasia: a multifaceted genetic disorder associated with defective signal transduction. Curr Opin immunol. 8: 459-464.

Leadon, S. A. \& Cooper, P. K. (1993) Preferential repair of ionizing radiation-induced damage in the transcribed strand of an active human gene is defective in Cockayne syndrome. Proc Natl Acad Sci U S A, 90, 10499-503.

Lehmann, A. R. (2001) The xeroderma pigmentosum group D (XPD) gene: one gene, two functions, three diseases. Genes Dev, 15, 15-23.

Lei, Y. C., Hwang, S. J., Chang, C. C., Kuo, H. W., Luo, J. C., Chang, M. J. \& Cheng, T. J. (2002) Effects on sister chromatid exchange frequency of polymorphisms in DNA repair gene XRCC1 in smokers. Mutat Res, 519, 93-101.

Leibeling, D., Laspe, P. \& Emmert, S. (2006) Nucleotide excision repair and cancer. J Mol Histol, 37, 225-38.

Levine, A. J. (1997) p53, the cellular gatekeeper for growth and division. Cell, 88, 323-31.

Liu, Y., Zhou, K., Zhang, H., Shugart, Y. Y., Chen, L., Xu, Z., Zhong, Y., Liu, H., Jin, L., Wei, Q., Huang, F., Lu, D. \& Zhou, L. (2008) Polymorphisms of LIG4 and XRCC4 
involved in the NHEJ pathway interact to modify risk of glioma. Hum Mutat, 29, 381-9.

Lunn, R. M., Helzlsouer, K. J., Parshad, R., Umbach, D. M., Harris, E. L., Sanford, K. K. \& Bell, D. A. (2000) XPD polymorphisms: effects on DNA repair proficiency. Carcinogenesis, 21, 551-5.

Matakidou, A., Eisen, T. \& Houlston, R. S. (2003) TP53 polymorphisms and lung cancer risk: a systematic review and meta-analysis. Mutagenesis, 18, 377-85.

Matsuura, S., Kobayashi, J., Tauchi, H. \& Komatsu, K. (2004) Nijmegen breakage syndrome and DNA double strand break repair by NBS1 complex. Adv Biophys, 38, 65-80.

Matullo, G., Palli, D., Peluso, M., Guarrera, S., Carturan, S., Celentano, E., Krogh, V., Munnia, A., Tumino, R., Polidoro, S., Piazza, A. \& Vineis, P. (2001) XRCC1, XRCC3, $\mathrm{XPD}$ gene polymorphisms, smoking and (32)P-DNA adducts in a sample of healthy subjects. Carcinogenesis, 22, 1437-45.

Menoyo, A., Alazzouzi, H., Espin, E., Armengol, M., Yamamoto, H. \& Schwartz, S., Jr. (2001) Somatic mutations in the DNA damage-response genes ATR and CHK1 in sporadic stomach tumors with microsatellite instability. Cancer Res, 61, 7727-30.

Miller, R. D., Phillips, M. S., Jo, I., Donaldson, M. A., Studebaker, J. F., Addleman, N., Alfisi, S. V., Ankener, W. M., Bhatti, H. A., Callahan, C. E., Carey, B. J., Conley, C. L., Cyr, J. M., Derohannessian, V., Donaldson, R. A., Elosua, C., Ford, S. E., Forman, A. M., Gelfand, C. A., Grecco, N. M., Gutendorf, S. M., Hock, C. R., Hozza, M. J., Hur, S., In, S. M., Jackson, D. L., Jo, S. A., Jung, S. C., Kim, S., Kimm, K., Kloss, E. F., Koboldt, D. C., Kuebler, J. M., Kuo, F. S., Lathrop, J. A., Lee, J. K., Leis, K. L., Livingston, S. A., Lovins, E. G., Lundy, M. L., Maggan, S., Minton, M., Mockler, M. A., Morris, D. W., Nachtman, E. P., Oh, B., Park, C., Park, C. W., Pavelka, N., Perkins, A. B., Restine, S. L., Sachidanandam, R., Reinhart, A. J., Scott, K. E., Shah, G. J., Tate, J. M., Varde, S. A., Walters, A., White, J. R., Yoo, Y. K., Lee, J. E., BoyceJacino, M. T. \& Kwok, P. Y. (2005) High-density single-nucleotide polymorphism maps of the human genome. Genomics, 86, 117-26.

Park, J. Y., Lee, S. Y., Jeon, H. S., Bae, N. C., Chae, S. C., Joo, S., Kim, C. H., Park, J. H., Kam, S., Kim, I. S. \& Jung, T. H. (2002) Polymorphism of the DNA repair gene XRCC1 and risk of primary lung cancer. Cancer Epidemiol Biomarkers Prev, 11, 23-7.

Ponder, B. A. (2001) Cancer genetics. Nature, 411, 336-41.

Rahman, N., Seal, S., Thompson, D., Kelly, P., Renwick, A., Elliott, A., Reid, S., Spanova, K., Barfoot, R., Chagtai, T., Jayatilake, H., Mcguffog, L., Hanks, S., Evans, D. G., Eccles, D., Easton, D. F. \& Stratton, M. R. (2007) PALB2, which encodes a BRCA2interacting protein, is a breast cancer susceptibility gene. Nat Genet, 39, 165-7.

Ramachandran, S., Ramadas, K., Hariharan, R., Rejnish Kumar, R. \& Radhakrishna Pillai, M. (2006) Single nucleotide polymorphisms of DNA repair genes XRCC1 and XPD and its molecular mapping in Indian oral cancer. Oral Oncol, 42, 350-62.

Renwick, A., Thompson, D., Seal, S., Kelly, P., Chagtai, T., Ahmed, M., North, B., Jayatilake, H., Barfoot, R., Spanova, K., Mcguffog, L., Evans, D. G., Eccles, D., Easton, D. F., Stratton, M. R. \& Rahman, N. (2006) ATM mutations that cause ataxiatelangiectasia are breast cancer susceptibility alleles. Nat Genet, 38, 873-5.

Ritchey, J. D., Huang, W. Y., Chokkalingam, A. P., Gao, Y. T., Deng, J., Levine, P., Stanczyk, F. Z. \& Hsing, A. W. (2005) Genetic variants of DNA repair genes and prostate cancer: a population-based study. Cancer Epidemiol Biomarkers Prev, 14, 1703-9. 
Roddam, P. L., Rollinson, S., O'driscoll, M., Jeggo, P. A., Jack, A. \& Morgan, G. J. (2002) Genetic variants of NHEJ DNA ligase IV can affect the risk of developing multiple myeloma, a tumour characterised by aberrant class switch recombination. J Med Genet, 39, 900-5.

Schmidt, M. K., Reincke, S., Broeks, A., Braaf, L. M., Hogervorst, F. B., Tollenaar, R. A., Johnson, N., Fletcher, O., Peto, J., Tommiska, J., Blomqvist, C., Nevanlinna, H. A., Healey, C. S., Dunning, A. M., Pharoah, P. D., Easton, D. F., Dork, T. \& Van't Veer, L. J. (2007) Do MDM2 SNP309 and TP53 R72P interact in breast cancer susceptibility? A large pooled series from the breast cancer association consortium. Cancer Res, 67, 9584-90.

Shen, H., Wang, X., Hu, Z., Zhang, Z., Xu, Y., Hu, X., Guo, J. \& Wei, Q. (2004) Polymorphisms of DNA repair gene XRCC3 Thr241Met and risk of gastric cancer in a Chinese population. Cancer Lett, 206, 51-8.

Shields, P. G. \& Harris, C. C. (2000) Cancer risk and low-penetrance susceptibility genes in gene-environment interactions. J Clin Oncol, 18, 2309-15.

Spry, M., Scott, T., Pierce, H. \& D'orazio, J. A. (2007) DNA repair pathways and hereditary cancer susceptibility syndromes. Front Biosci, 12, 4191-207.

Sreeja L, Syamala V, Raveendran PB, Santhi S, Madhavan J, Ankathil R., (2008). P53 Arg72Pro polymorphism Predicts Survival Outcome in Lung Cancer Patients in Indian Population. Cancer Investigation, 26:41-46.

Sreeja, L., Syamala, V. S., Syamala, V., Hariharan, S., Raveendran, P. B., Vijayalekshmi, R. V., Madhavan, J. \& Ankathil, R. (2007) Prognostic importance of DNA repair gene polymorphisms of XRCC1 Arg399Gln and XPD Lys751Gln in lung cancer patients from India. J Cancer Res Clin Oncol, 134, 645-52.

Stern, M. C., Conti, D. V., Siegmund, K. D., Corral, R., Yuan, J. M., Koh, W. P. \& Yu, M. C. (2007) DNA repair single-nucleotide polymorphisms in colorectal cancer and their role as modifiers of the effect of cigarette smoking and alcohol in the Singapore Chinese Health Study. Cancer Epidemiol Biomarkers Prev, 16, 2363-72.

Tang, D., Cho, S., Rundle, A., Chen, S., Phillips, D., Zhou, J., Hsu, Y., SCHNABEL, F., ESTABROOK, A. \& PERERA, F. P. (2002) Polymorphisms in the DNA repair enzyme XPD are associated with increased levels of PAH-DNA adducts in a casecontrol study of breast cancer. Breast Cancer Res Treat, 75, 159-66.

Tomlinson, I. P., Webb, E., Carvajal-Carmona, L., Broderick, P., Howarth, K., Pittman, A. M., Spain, S., Lubbe, S., Walther, A., Sullivan, K., Jaeger, E., Fielding, S., Rowan, A., Vijayakrishnan, J., Domingo, E., Chandler, I., Kemp, Z., Qureshi, M., Farrington, S. M., Tenesa, A., Prendergast, J. G., Barnetson, R. A., Penegar, S., Barclay, E., Wood, W., Martin, L., Gorman, M., Thomas, H., Peto, J., Bishop, D. T., Gray, R., Maher, E. R., Lucassen, A., Kerr, D., Evans, D. G., Schafmayer, C., Buch, S., Volzke, H., Hampe, J., Schreiber, S., John, U., Koessler, T., Pharoah, P., Van Wezel, T., Morreau, H., Wijnen, J. T., Hopper, J. L., Southey, M. C., Giles, G. G., Severi, G., Castellvi-Bel, S., Ruiz-Ponte, C., Carracedo, A., Castells, A., Forsti, A., Hemminki, K., Vodicka, P., Naccarati, A., Lipton, L., Ho, J. W., Cheng, K. K., Sham, P. C., Luk, J., Agundez, J. A., Ladero, J. M., De La Hoya, M., Caldes, T., Niittymaki, I., Tuupanen, S., Karhu, A., Aaltonen, L., Cazier, J. B., Campbell, H., Dunlop, M. G. \& Houlston, R. S. (2008) A genome-wide association study identifies colorectal cancer susceptibility loci on chromosomes 10p14 and 8q23.3. Nat Genet, 40, 623-30. 
Tseng, R. C., Hsieh, F. J., Shih, C. M., Hsu, H. S., Chen, C. Y. \& Wang, Y. C. (2009) Lung cancer susceptibility and prognosis associated with polymorphisms in the nonhomologous end-joining pathway genes: a multiple genotype-phenotype study. Cancer, 115, 2939-48.

Weston, A., Perrin, L. S., Forrester, K., Hoover, R. N., Trump, B. F., Harris, C. C. \& Caporaso, N. E. (1992) Allelic frequency of a p53 polymorphism in human lung cancer. Cancer Epidemiol Biomarkers Prev, 1, 481-3.

Whibley, C., Pharoah, P. D. \& Hollstein, M. (2009) p53 polymorphisms: cancer implications. Nat Rev Cancer, 9, 95-107.

Wood, R. D., Mitchell, M. \& Lindahl, T. (2005) Human DNA repair genes. Mutat Res, 577, 275-83.

Yin, J., Vogel, U., Ma, Y., Guo, L., Wang, H. \& Qi, R. (2006) Polymorphism of the DNA repair gene ERCC2 Lys751Gln and risk of lung cancer in a northeastern Chinese population. Cancer Genet Cytogenet, 169, 27-32.

Zhou, G., Zhang, X., Lui, S., Lin, D., Liang, C. \& Yang, X. (2001) [Pilot study on mutations of p53 gene in laryngeal carcinoma]. Hua Xi Yi Ke Da Xue Xue Bao, 32, 359-60, 434.

Zhou, W., Liu, G., Miller, D. P., Thurston, S. W., Xu, L. L., Wain, J. C., Lynch, T. J., Su, L. \& Christiani, D. C. (2003) Polymorphisms in the DNA repair genes XRCC1 and ERCC2, smoking, and lung cancer risk. Cancer Epidemiol Biomarkers Prev, 12, 359-65.

Zienolddiny, S., Campa, D., Lind, H., Ryberg, D., Skaug, V., Stangeland, L., Phillips, D. H., Canzian, F. \& Haugen, A. (2006) Polymorphisms of DNA repair genes and risk of non-small cell lung cancer. Carcinogenesis, 27, 560-7. 


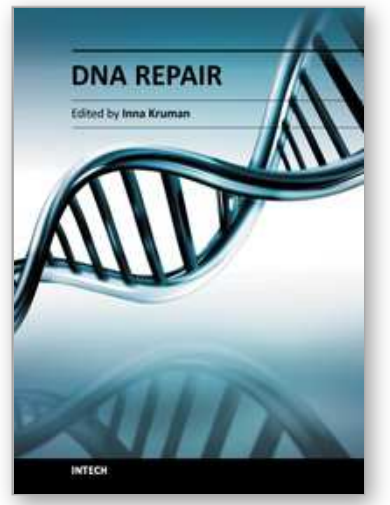

\author{
DNA Repair \\ Edited by Dr. Inna Kruman
}

ISBN 978-953-307-697-3

Hard cover, 636 pages

Publisher InTech

Published online 07, November, 2011

Published in print edition November, 2011

The book consists of 31 chapters, divided into six parts. Each chapter is written by one or several experts in the corresponding area. The scope of the book varies from the DNA damage response and DNA repair mechanisms to evolutionary aspects of DNA repair, providing a snapshot of current understanding of the DNA repair processes. A collection of articles presented by active and laboratory-based investigators provides a clear understanding of the recent advances in the field of DNA repair.

\title{
How to reference
}

In order to correctly reference this scholarly work, feel free to copy and paste the following:

Ravindran Ankathil (2011). Low Penetrance Genetic Variations in DNA Repair Genes and Cancer Susceptibility, DNA Repair, Dr. Inna Kruman (Ed.), ISBN: 978-953-307-697-3, InTech, Available from: http://www.intechopen.com/books/dna-repair/low-penetrance-genetic-variations-in-dna-repair-genes-andcancer-susceptibility

\section{INTECH}

open science | open minds

\section{InTech Europe}

University Campus STeP Ri

Slavka Krautzeka 83/A

51000 Rijeka, Croatia

Phone: +385 (51) 770447

Fax: +385 (51) 686166

www.intechopen.com

\section{InTech China}

Unit 405, Office Block, Hotel Equatorial Shanghai

No.65, Yan An Road (West), Shanghai, 200040, China 中国上海市延安西路65号上海国际贵都大饭店办公楼 405 单元

Phone: +86-21-62489820

Fax: $+86-21-62489821$ 
(C) 2011 The Author(s). Licensee IntechOpen. This is an open access article distributed under the terms of the Creative Commons Attribution 3.0 License, which permits unrestricted use, distribution, and reproduction in any medium, provided the original work is properly cited. 